\title{
The Effect of Carbon Content in Martensite on the Strength of Dual Phase Steel
}

\author{
P.D. Sudersanan, Nagaraj Kori, S. Aprameyan and Dr.U.N. Kempaiah
}

\begin{abstract}
The objective of this investigation is to study the variation of strength of dual phase steel with the percentage of carbon content in the martensite phase. The study is conducted on samples of dual phase steel prepared by intercritical annealing process with temperature varying from $730^{\circ} \mathrm{C}$ to $810^{\circ} \mathrm{C}$. In this process both coarse and fine ferritemartensite structures are produced with volume fraction of martensite varying from 48 to 69\%. It has been observed from the investigation that both yield strength and tensile strength increased with increasing carbon content in the martensite phase of dual phase steel up to $0.195 \%$ and then decreased. The optimum values of strength are observed at $0.195 \%$ of carbon.
\end{abstract}

Keywords--- Dual Phase Steel, Intercritical Temperature, Microstructure, Volume Fraction

\section{INTRODUCTION}

$\mathrm{E}$ VER growing demand for newer materials with improved mechanical properties has led to the development of wide variety of dual phase steels. Intercritical heat treatment is an effective way to transform low carbon steels to dual phase steels with superior strength. The heat treatment involves heating the steel to intercritical temperature range to obtain ferrite and austenite followed by quenching to get ferritemartensite dual phase structure. These steels have high strength, ductility, toughness, high initial strain hardening and exhibit continuous yielding. In dual phase steel martensite is dispersed in a soft ductile ferrite matrix.

It is known that the strength of dual phase steel is strongly influenced by the volume fraction of martensite present in it. The present investigation is to study the variation of strength with the carbon content present in the martensite phase of dual phase steel.

\section{LITERATURE SURVEY}

The dual phase steels with a high strength to weight ratio have created great interest in the automotive sector [1]-[4]. The dual phase heat treatment can be applied to low-carbon

P.D.Sudersanan, Assistant Professor \& Head, Dept. of Mechanical Engineering, Dr.T.Thimmaiah Institute of Technology, K.G.F, India.

E-mail: sudersan.ponathil@gmail.com.

Nagaraj Kori, Assistant Professor, Dept. of Mechanical Engineering, R.Y.M.Engineering College, Bellary, India.

E-mail: kori.nagraj67@gmail.com.

Aprameyan.S, Professor \& Head, Dept. of Mechanical Engineering, Byregowda Institute of Technology, Kolar, India.

E-mail: aprameyan.seetharam@gmail.com.

Dr.U.N.Kempaiah, Professor \& Head, Dept. of Mechanical Engineering, Govt. Engineering college, Ramanagar, India.

E-mail: unkemp@ rediffmail.com steels with carbon content higher than $0.1 \%$ and to specimens which have sections larger than $1.0 \mathrm{~mm}$ [5]. Dual phase steels are identified as a class of HSLA steels designated by a composite microstructure constituted by hard martensite phase dispersed in the soft ferrite matrix. Dual phase steels possess high tensile strength, high work hardening rate at the starting of plastic deformation and also possess good ductility. These favourable properties are due to dual phase structure of dual phase steel. The soft ferrite phase provides the required ductility where as the hard phase martensite imparts the required strength [6], [7]. Dual phase steels also possess continuous yielding behaviour, uniform plastic deformation and good formability [8]. The hardness of dual phase steel is considerably improved due to the presence of harder martensite phase compared to the normal steel with ferrite pearlite microstructure [9], [10].

Till date many researchers have tried to correlate the yield strength and tensile strength of intercritically annealed steels with the volume fraction of martensite in the dual phase microstructure [11]-[13]. Several attempts have been made to establish the overall mechanical properties of dual phase steels from the properties of individual constituents using the law of mixtures [14]. One of the important parameter which decides the mechanical properties of dual phase steel is the carbon content in the martensite phase [15]. No systematic study is reported in the literature relating the carbon content in the martensite phase and the strength of dual phase steel.

\section{Methodology}

The composition of HSLA steel samples were tested using Optical Emission Spectrometer and Carbon \& Sulphur analyser. The composition obtained after the analysis of the base metal is tabulated in table 1 .

Table 1: Chemical Composition of Specimen

\begin{tabular}{|c|c|}
\hline Element & Weight $\%$ \\
\hline $\mathrm{C}$ & 0.13 \\
\hline $\mathrm{Mn}$ & 1.18 \\
\hline $\mathrm{S}$ & 0.010 \\
\hline $\mathrm{P}$ & 0.001 \\
\hline $\mathrm{Si}$ & 0.30 \\
\hline $\mathrm{Cr}$ & 0.047 \\
\hline $\mathrm{Mo}$ & 0.057 \\
\hline $\mathrm{B}$ & 0.001 \\
\hline $\mathrm{Ni}$ & 0.048 \\
\hline
\end{tabular}

All specimens are cut into sizes of $100 \mathrm{~mm} \times 100 \mathrm{~mm} \times$ $14 \mathrm{~mm}$. They are first austenized by heating using an electrical 
Muffle furnace in batches. They are heated to $920^{\circ} \mathrm{C}$ which is above the austenizing temperature for low carbon steels. The specimens are held at $920^{\circ} \mathrm{C}$ for 30 minutes and then quenched in $9 \%$ iced brine solution at $-7^{\circ} \mathrm{C}$. The $\mathrm{Fe}-\mathrm{C}$ diagram and the heat treatment cycle adopted are shown in figures 1 and 2 respectively.

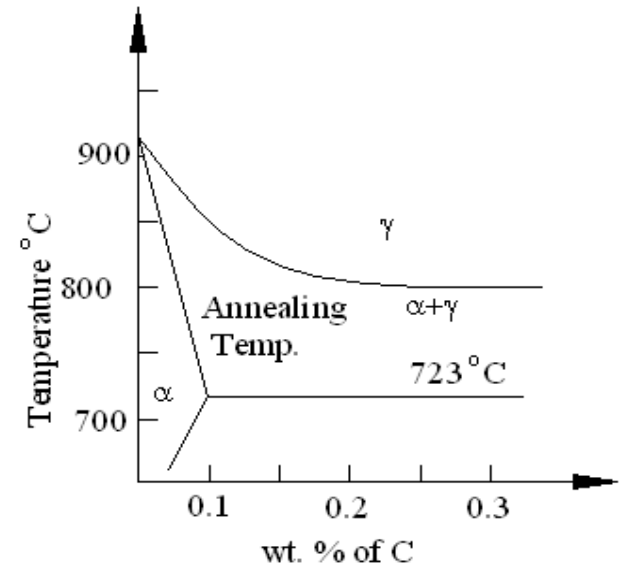

Figure 1: Fe-C Equilibrium Diagram for Intercritical Annealing Heat Treatment

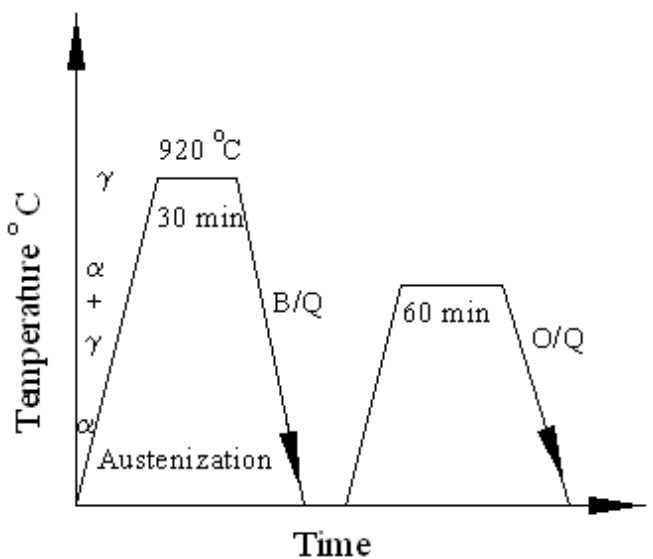

Figure 2: Intercritical Annealing Cycle

The critical annealing temperatures of the base metal are estimated using Andrew's equation [16], [17]. The lower and upper critical temperatures are approximated as $720^{\circ} \mathrm{C}$ and $816^{\circ} \mathrm{C}$ respectively. The specimens are then heated to different intercritical temperatures ranging from $730^{\circ} \mathrm{C}$ to $810^{\circ} \mathrm{C}$ before finally quenched in Servo quench 707 oil at $25^{\circ} \mathrm{C}$ to obtain dual phase microstructure. The microstructures of the different specimens were obtained using metallurgical microscope at 1000X magnification. The tensile test specimens were prepared from the different samples and tested for their yield strength and ultimate tensile strength as per ASTM E8M standard.

\section{RESUlt AND DisCUSSION}

The percentage of ferrite and martensite in the different samples of dual phase steel are measured using point counting method as per ASTM E562 standard. The micrographs show two distinct regions, ferrite (white region) and martensite (dark region). The percentage of martensite in the dual phase steel is influenced by the intercritical annealing temperature. It is found that the volume fraction of martensite increases nonlinearly with intercritical annealing temperature. Fig.3 shows the variation of volume fraction of martensite with the intercritical annealing temperatures.

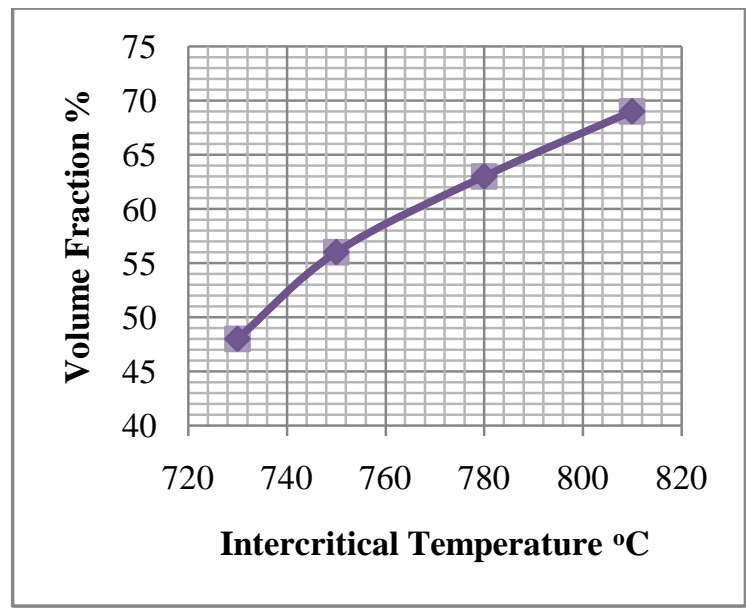

Figure 3: Volume Fraction v/s Intercritical Temperature

The dual phase steel obtained after heat treatment consists of a strong second phase predominantly of martensite but may contain retained austenite and/or bainite. The strong second phase martensite is dispersed in a soft ductile ferrite matrix and it provides the strength for the dual phase steel, whereas, the ferrite provides the required ductility. The microstructures of samples are shown in fig.4.

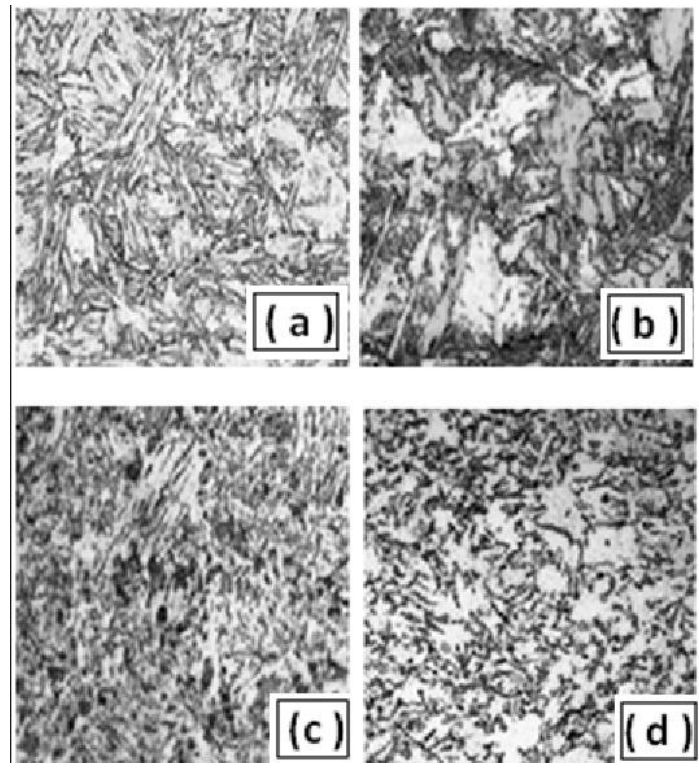

Figure 4: Microstructure of DP Steel Samples (a) $730^{\circ} \mathrm{C}$ (B) $750^{\circ} \mathrm{C}$ (C) $780^{\circ} \mathrm{C}$ (D) $810^{\circ} \mathrm{C}$

Fig. 5 shows the yield and tensile strength of steel plotted against the volume fraction of martensite. The strength increased with the martensite volume fraction initially and later for higher percentage of martensite the strength is found to decrease as suggested by some researchers. 


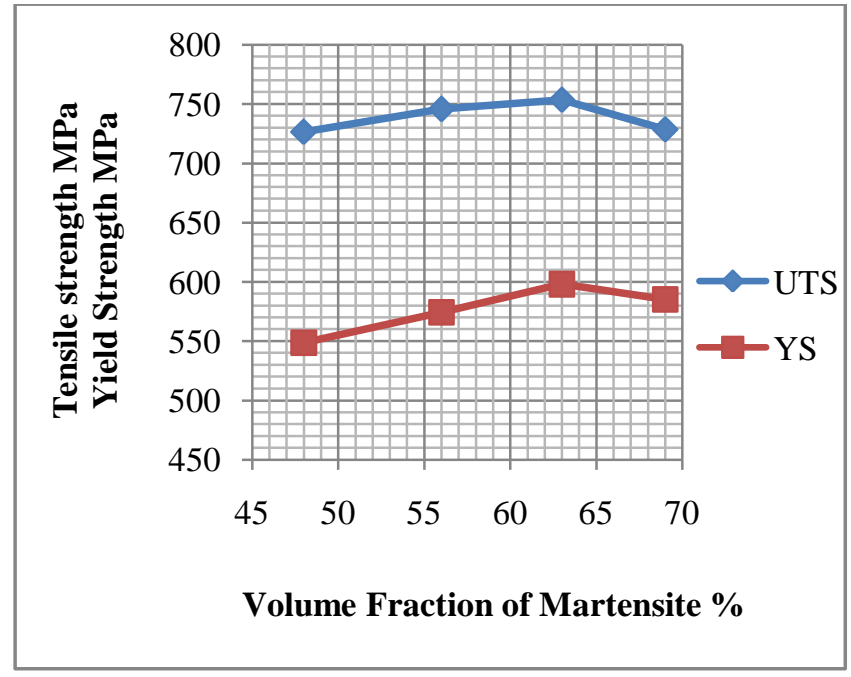

Figure 5: Yield and Tensile Strength v/s Volume Fraction of Martensite

One of the important parameter which affects the mechanical properties of dual phase steel is the percentage of carbon content in the martensite phase. Assuming the carbon content in the ferrite phase as $0.02 \%$ which is the solubility limit for carbon in the ferrite[18], carbon content in the martensite phase is calculated using the law of mixtures (equation 1).

$$
\mathrm{C}=\mathrm{C}_{\mathrm{f}} \mathrm{V}_{\mathrm{f}}+\mathrm{C}_{\mathrm{m}} \mathrm{V}_{\mathrm{m}}
$$

Where $\mathrm{C}$ is the mean carbon content in the base metal and $\mathrm{C}_{\mathrm{f}}$ and $\mathrm{C}_{\mathrm{m}}$ are the carbon content in the ferrite and martensite phases respectively. $V_{f}$ and $V_{m}$ are the Volume fractions in the ferrite and martensite phases. The carbon content in the martensite is found to decrease with the volume fraction of martensite. The variation of carbon content with the martensite is shown in fig.6.

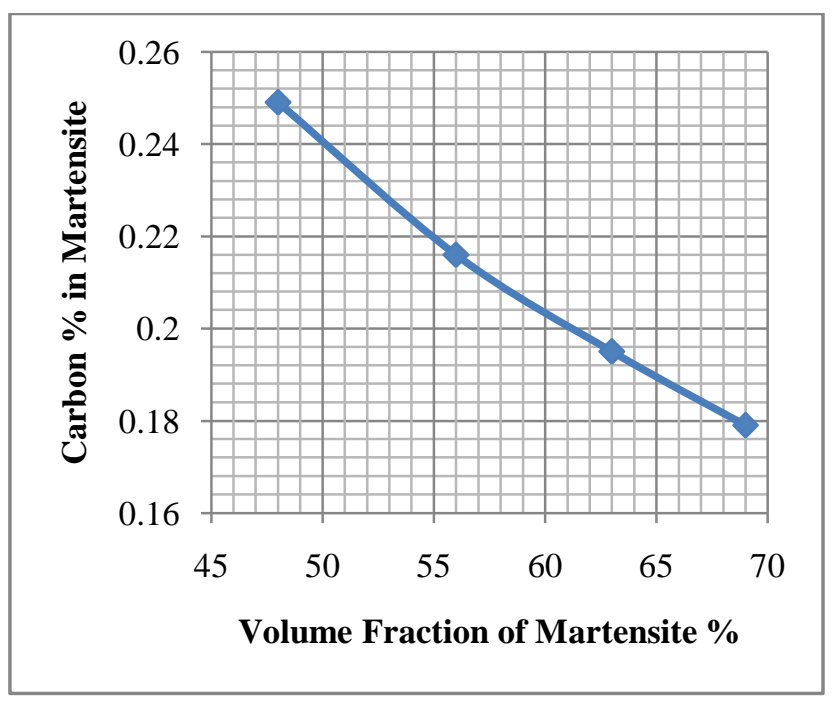

Figure 6: Carbon \% in Martensite v/s Volume Fraction

The yield strength and tensile strength has shown a marginal improvement with the carbon content in martensite in the initial stages and then started to decline beyond 0.195 $\%$. These variations are shown in fig. 7 .

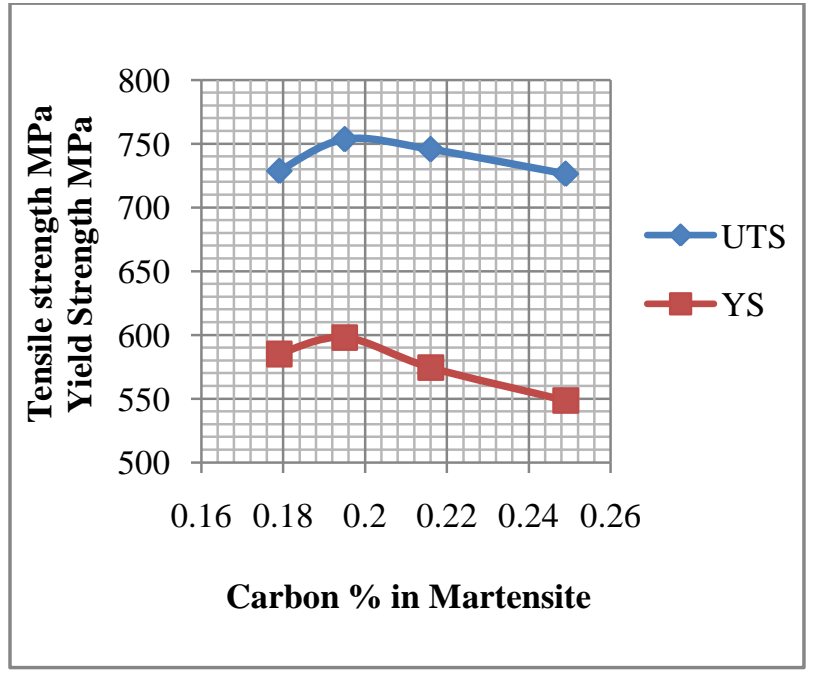

Figure 7: Yield and Tensile Strength v/s Carbon \% in Martensite

\section{CONCLUSION}

Dual phase steel can be produced by intercritical annealing for the steel investigated starting from $720^{\circ} \mathrm{C}$ (lower critical temperature) to $816^{\circ} \mathrm{C}$ (upper critical temperature). The Intercritical temperature has shown a considerable influence on the volume fraction of the dual phase steel as suggested by the previous researchers. Volume fraction of martensite increased nonlinearly with intercritical temperature.

Investigations were carried out on various samples to study the effect of percentage of carbon content in the martensite phase of the dual phase steel on the strength imparted to it. Since the solubility of carbon in ferrite is limited the carbon content in martensite decreases with an increase in volume fraction of martensite. An increase in carbon content in martensite to a certain limit increases both yield strength and ultimate tensile strength. In this study yield strength and tensile strength was found to increase initially with carbon content up to $0.195 \%$ and then decreased marginally thereafter with carbon content in the martensite phase.

Finally to conclude dual phase steels with high martensite volume fraction $(>60 \%)$ have shown an improvement in strength with an increase in carbon percentage in martensite. 


\section{REFERENCES}

[1] K Hulka, "Dual phase and Trip steels", ASM Metals Park Ohio, Pp.14, 2000.

[2] S Hayami, T Furukawa, "Microalloying 75", Proceedings of International Symposium on HSLA alloys, Washington D.C., Pp. 311320, 1977.

[3] M S Rashid, "G.M 980X-A Unique strength sheet steel with superior formability", SAE, No. 760206, Pp. 23-27, 1976.

[4] Bode R, Meurer M, Schaumann T W, Warnechew, "Selection and use of coated advanced high strength steels for automotive applications", Proceedings of the Galvatech conference, Chicago, USA, Pp.107-108, 2004.

[5] Oguzhan Kelesternur, M Halidun Kelestemur, Servet Yildiz, "Improvement of Mechanical Properties of Reinforcing Steel Used in the Reinforced Concrete Structures", Journal of Iron and Steel Research, International, Vol. 16, No. 3, Pp. 55-63, 2009.

[6] Hills D J, Llewellyn D T, Evans P J, "Rapid Annealing of Dual-Phase Steels", Iron making and Steel making, Vol. 25, No.1, Pp. 47-54, 1998.

[7] Davies R G, Magee C L, "Structure and Properties of Dual-Phase Steels", The Metallurgical Society of AIME, Warrendale, PA, Pp. 1-19, 1979.

[8] Rashid M S, "Formable HSLA and dual phase steels", Proceedings of the Metallurgical society of AIME, Michigan, USA, Pp. 1-24, 1979.

[9] R G Davies, "Influence of martensite composition and content on the properties of dual phase steels", Metall. Transactions: A, Vol. 9, Pp. 671-679, 1978.

[10] A Kumar, S B Sing, K K Ray, "Influence of bainite-martensite content on the tensile properties of low carbon dual phase steels", Material Science and. Engineering: A, Vol. 474, No.1-2, Pp. 270-282, 2008.

[11] Ahmad Zare, A Ekrami, "Influence of martensite volume fraction on tensile properties of triple phase ferrite-bainite-martensite steels", Materials Science and Engineering: A, Vol. 530, Pp. 440-445, 2011.

[12] Thak Sang Byun, In Sup Kim, "Tensile properties and inhomogeneous deformation of ferrite-martensite dual-phase steels", Journal of Material Science, Vol. 28, No.11, Pp. 2923-2932, 1993.

[13] Asim Bag, Ray K K, "A new model to explain the unusual tensile behaviour of high martensite dual-phase steels", Metallurgical and materials Transactions: A, Vol. 32, No.9, Pp. 2400-2403, 2001.

[14] G Thomas and J Y Koo, "Structure and properties of dual phase steels", AIME, NewYork, Pp. 183-201, 1979

[15] Ebrahim Najafi Birgani, Majid Pouramani, "Effect of martensite volume fraction on the work hardening behaviour of dual phase steels", Proceedings of Metal 2009, 18th international metall. conference, Hradecnad Moravicí, Czech Republic, Pp.19-21, 2009.

[16] K W Andrews, "Empirical formulae for the calculation of some transformation temperatures", Journal of the Iron and Steel Institute Vol. 203, Pp. 721-727, 1965.

[17] Antonio Augusto Gorni, "Steel forming and heat treating handbook", 2012 edition.

[18] Flake C Campbell, "Elements of metallurgy and Engineering", 2008 edition. 